\title{
THE USE OF BORAX PENTAHYDRATE OF INORGANIC FILLER IN MEDIUM DENSITY FIBERBOARD PRODUCTION
}

\author{
Mehmet Akgül, ${ }^{1, \AA}$ \\ https://orcid.org/0000-0002-1492-3979 \\ Osman Çamlıbel ${ }^{2}$ \\ https://orcid.org/0000-0002-8766-1316
}

\begin{abstract}
The aim of the study was the use of the inorganic borax pentahydrate mineral in medium density fiberboard production instead of biomass fiber and to specify the performance which physical, mechanical, combustion of produced boards. Chips used in manufacture were subjected to cooking for 4,5 minutes in Asplund defibrator at the vapor pressure of $7,6 \mathrm{~kg} / \mathrm{cm}^{2}$ pressure and $190{ }^{\circ} \mathrm{C}$ temperature. $1,6 \%$ paraffin based on oven-dried wood fibers was added to cooked chips before the fiber processing in segments of defibrillator section. $1 \%$ ammonium sulfate based on oven-dried wood fibers were added to fiber in the bowline. Borax pentahydrate was prepared in a separate tank in order to use the production of medium density fiberboard. Borax pentahydrate inorganic mineral was mixed with urea-formaldehyde resin. Urea-formaldehyde glue was prepared as three different solutions including the borax pentahydrate as $3 \%(20 \mathrm{~kg}), 6 \%(40 \mathrm{~kg})$ and $9 \%$ $(60 \mathrm{~kg})$ respectively. Borax pentahydrate mixed fibers were dried to $12 \%$ moisture. Mat was formed before prepress. Daily multi-press was manufactured at $188{ }^{\circ} \mathrm{C}$ temperature and $32 \mathrm{~kg} / \mathrm{cm}^{2}$ pressure and, 270 second pressing time. Manufactured boards size were $2100 \times 4900 \times 18(\mathrm{~mm})$. According to this work result, $3 \%$ and $6 \%$ rate borax pentahydrate added medium density fiberboard boards were measured more good physical and mechanical test results compare to control boards. $9 \%$ borax pentahydrate added medium density fiberboard boards were shown incredibly superior performance at fire resistance.
\end{abstract}

Keywords: Biomass fiber, borax pentahydrate, color properties, combustion temperature, mechanical properties, medium density fiberboard, physical properties.

\section{INTRODUCTION}

The number of production increases day by day in the boron and boron derivatives forest products plate production sector. Boron and boron derivatives are used effectively in the production of composite plates due to their resistance to fire. Scientific studies on the effective use of boron derivatives chemicals in the production of forest products are carried out all over the world.

Borates have several important advantages in addition to their preservative features such as imparting flame retardant, providing sufficient protection against wood destroying organisms, having low mammalian toxicity and low volatility. Moreover, they are colorless and odorless. Baysal and Yalinkiliç (2005) have

\footnotetext{
${ }^{1}$ Necmettin Erbakan University, S. Ahmet Cengiz Engineering Faculty, Department of Materials and Metallurgical Engineering, Seydişehir, Konya, Turkey.

${ }^{2}$ Kırıkkale University, Kırıkkale Vocational School, Interior Design Program, Kirikkale. Turkey.

•Corresponding author: mehmetakgul@erbakan.edu.tr
}

Received: 13.01.2020 Accepted: 26.11.2020 
examined a comparative study on stability and decay resistance of some environmentally friendly fire retardant baron compounds in their study. Hafizoglu et al. (1994) have investigated various fire retardants to be used with MDF panels. The effects of fire retardants over the fire performance of MDF and plywood were determined and the results showed that the fire performance of MDF and plywood increased nearly $6,4 \%$ and $1,6 \%$ respectively.

Istek et al. (2013) investigated the effect of fire retardants on the combustion performance of medium-density fiberboards that were coated with mixtures of water, binder, calcite, and various fire-retardant coatings. Jiang et al. (2011) have researched the influence of three boron flame retardants on the thermal curing behavior of urea formaldehyde resin. Kurt et al. (2012) have studied the effects of many boron compounds (boric acid, borax, ammonium, among others ) used as fire retardants in wood. According to LeVan and Tran (1990), inorganic salts such as di-ammonium phosphate, mono ammonium phosphate, zinc chloride, ammonium sulfatesulfate, borax, and boric acid are the most common fire-retardant chemicals used for wood.

Ozcifc1 et al. (2007) have studied the fire properties of laminated veneer lumber (LVL) prepared from beech (Fagus orientalis L.) veneers treated with some fire retardants. According to their study, the lowest temperature and mass loss are obtained for specimens treated with di-ammonium phosphate and boric acid-borax mixture. Taghiyari and Nouri (2015) have investigated the influence of nano-wollastonite $(5,10$, 15 , and $20 \mathrm{~g} / \mathrm{kg}$ dry weight basis of wood fibers) on the physical and mechanical properties of MDF. According to the results, nano-wollastonite material contents of $10 \%$ and $15 \%$ are optimal. Taghiyari et al. (2016) have produced MDF from wollastonite fibers, camel-thorn, and wood fibers. According to studies, wollastonite fibers with the further addition of camel-thorn fibers improved most of the physical and mechanical properties of MDFs.

Tondi et al. (2014) have studied the comparison of di-sodium octaborate tetrahydrate-based and tannin-boron-based formulations as a fire retardants for wood structures. When the ratio of fire retardants in the wood panels is increased, it is found that their fire performances are improved even more (Tsunoda 2001). Such improvement is a significant outcome in wood industry. Usta and Ustaömer (2012) have examined the effect of some boron compounds for the physical and the mechanical properties of medium density fiberboard (MDF) panels in terms of the fire-retardant properties such as melamine urea-formaldehyde (MUF) resins having different melamine contents $(10 \%, 15 \%$, and $20 \%)$.

Valcheva and Savov (2015) have studied the effect of thickness of medium density fiberboard produced of hardwood tree species on their selected physical and mechanical properties. Yang and Qing (2014) have examined the effect of typical boron compounds on the thermal degradation and combustion properties of Phyllostachys pubescens. Yu et al. (2017) have studied the combustibility of boron-containing fire retardant treated bamboo filament. Zahedsheijani et al. (2011) have studied the potential use of $\mathrm{Na}+$ montmorillonite $(\mathrm{Na}+\mathrm{MMT})$ nanoclay in MDF production. According to the test results, the air permeability of MDF boards is decreased. The mass diffusivity of the board is not affected.

The production of MDF was about 4,910 million $\mathrm{m}^{3} / \mathrm{year}$ in 2018 in Turkey. However, this figure was about 99,443 million cubic meter/year in the world (accessed, 24 January 2020). Some researchers have performed various studies to reduce the number of raw materials in the MDF industry. These studies were about the usage possibilities of the borax pentahydrate minerals rather than lignocellulosic raw materials.

The inorganic borax pentahydrate mineral which has a mixing ratio of $0 \%, 3 \%, 6 \%, 9 \%$ respectively are produced for boards in the MDF production process. In this study, the experimental investigations are performed in order to realize the physical, mechanical, color and combustion properties of the produced boards having borax pentahydrate mineral according to the reference board. According to MDF boards combustion tests, Borax Pentahydrate inorganic mineral can be used for the fire as a resistive material in the production of MDF.

\section{MATERIAL AND METHODS}

\section{Materials}

Wood species used in MDF production are beech (Fagus orientalis L.), Oak (Quercus robur L) and Pine (Pinus sylvester L). These species were brought from Duzce Province forestry, West Black Sea Region and Bolu Province, respectively. 


\section{Borax pentahydrate}

Borax pentahydrate is produced in Eskişehir ETI mine (Etibor-48). Borax pentahydrate chemical formula $\mathrm{Na}_{2} \mathrm{~B}_{4} 0_{7} 5 \mathrm{H}_{2} 0$ density is as follows: $1,880 \mathrm{~g} / \mathrm{cm}^{3}$ with high abrasiveness. In the basic structure, the rombohedral crystal is a boron compound also known as tinkhanite. It could be rapidly crystallized in aqueous solutions above $60,8{ }^{\circ} \mathrm{C}$. Turkey is one of the world's richest countries in terms of boron reserves. Borax pentahydrate is in a lot of reserves in Bigadic, Emet, Kestelek, Kirka areas (accessed 22 June 2019).

Borax pentahydrate was prepared as a ratio of $40 \%$ solution in a separate tank. Then later, $40 \%$ borax pentahydrate solution was mixed to urea-formaldehyde resin with blender as homogenous. Mixed (BP+UF) were added fibers in the blowline.

\section{Chemicals}

The chemicals used in this study were urea-formaldehyde, liquid paraffin, and ammonium sulfate. These chemicals were brought from Polisan Company in Gebze, Mercan Chemistry in Denizli and from another company in Gebze, respectively.

Urea formaldehyde resin used in the production of MDF has the following technical specifications; solid $65 \%$, formaldehyde/urea molar ratio: 1,25 , density $\left(\right.$ at $\left.20{ }^{\circ} \mathrm{C} \mathrm{g} / \mathrm{cm}^{3}\right): 1,227$, viscosity $\left(20{ }^{\circ} \mathrm{C} \mathrm{cps}\right) 185$ seconds, gel time $\left(100{ }^{\circ} \mathrm{C}\right)\left(20 \%(\mathrm{NH} 4)_{2} \mathrm{SO}_{4}\right): 25-40$ second, $\mathrm{pH}: 7,5$ to 8,5 free formaldehyde content $0,5 \% \max$, methylol groups $12-15 \%$, average shelf life is 45 days.

Hardener; the ammonium sulfate was supplied from a private company from Izmit (Turkey), the catalyst was $20 \%$ ammonium sulfate $(\mathrm{NH} 4)_{2} \mathrm{SO}_{4}$ solution (density of $0,95 \mathrm{~g} / \mathrm{cm}^{3}$ and $\mathrm{pH} 6,5$ ).

Paraffin (wax); the paraffin was dirty white and liquid form, it had a solid content of $60 \%$, the pH was 9, viscosity was 13 second, and the density was $0,96 \mathrm{~g} / \mathrm{cm}^{3}$. The liquid paraffin was supplied from Mercan Chemistry in Denizli (Turkey).

\section{Methods}

Provided that the other production conditions are the same, the test boards that are produced by changing the ratio of the borax pentahydrate mixture are the general-purpose boards. Divapan Integrated Wood Company produce these products. The product process flow sheet is shown in Figure 1.

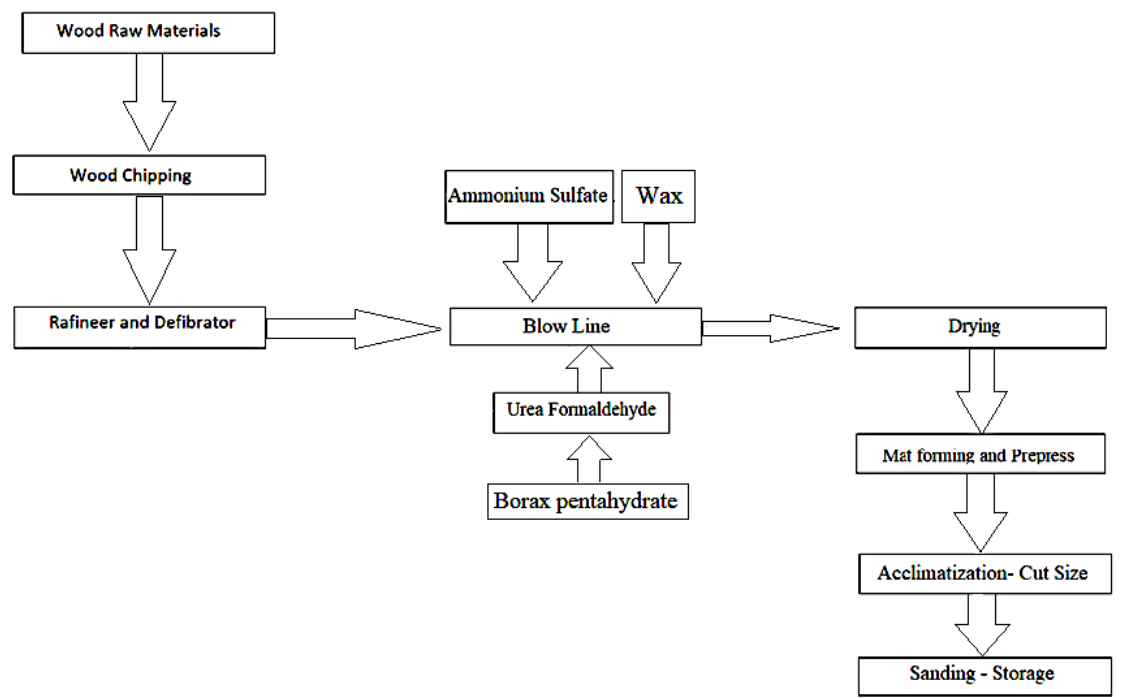

Figure 1: Product process flow sheet. 
It mixes the resins and other chemicals in the glue unit. The borax pentahydrate inorganic mineral solution is prepared in the solution preparing tank. Then these chemicals, which are prepared in the tank are mixed and then the mixture is sent to the blowline. This process and applications are the main topics of this study. The preparation of the resin, inorganic borax pentahydrate solution and other chemicals are shown in Figure 2.

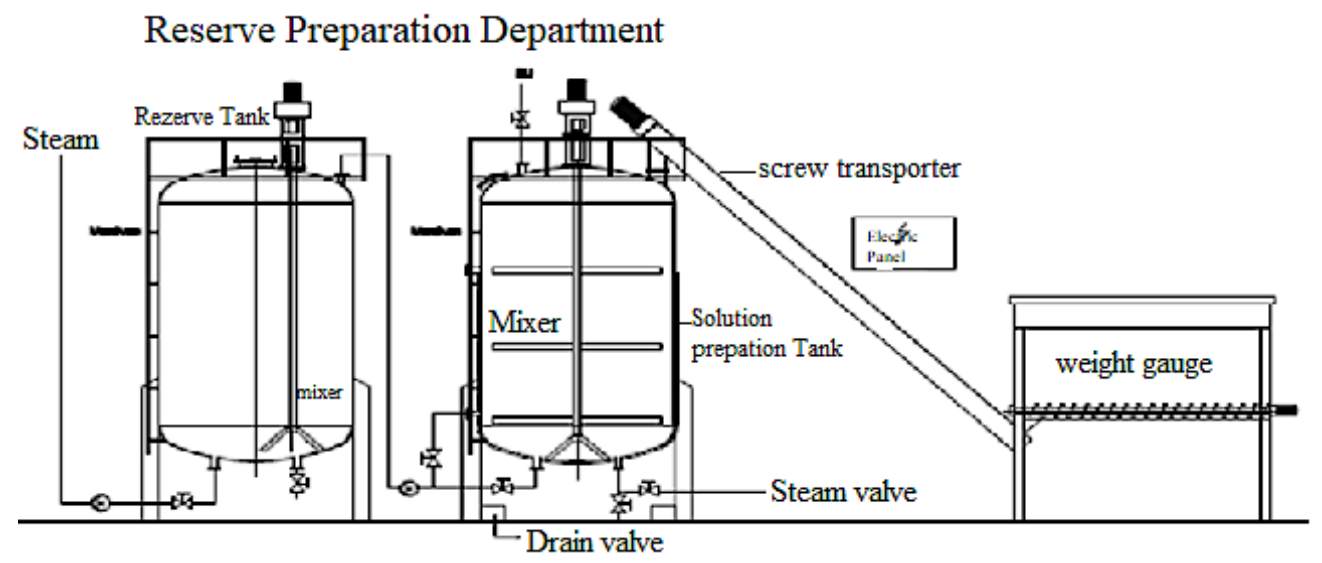

Figure 2: Preparation of the resin, inorganic borax pentahydrate solution and other chemicals.

\section{Product parameters}

Production parameters are shown in Table 1. The addition of inorganic borax pentahydrate solution and other chemicals to lignocellulosic biomass are presented. The symbols in Table 1 correspond that $\mathrm{R}$ defines the consumed wood fibers for $1 \mathrm{~m}^{3}$ board, B defines the consumed borax pentahydrate minerals for $1 \mathrm{~m}^{3}$ board, $\mathrm{x}$ and y subscripts define the percentage (\%) of the mixture.

Table 1: Board content.

\begin{tabular}{|c|c|c|c|c|c|c|c|c}
\hline Groups & Product & Biomass & Resin & Hardener & Paraffin & $\begin{array}{c}\text { Inorganic } \\
\text { additive }\end{array}$ & $\begin{array}{c}\text { Industrial } \\
\text { fibres }\end{array}$ & Ratio \\
\hline $\mathrm{R}_{100} \mathrm{~B}_{0}$ & $\mathrm{MDF}^{\mathrm{a}}$ & $\mathrm{L}^{\mathrm{b}}$ & $\mathrm{UF}^{\mathrm{c}}$ & $\mathrm{AS}^{\mathrm{d}}$ & $\mathrm{Wax}$ & - & $100 \%$ & 0 \\
\hline $\mathrm{R}_{97} \mathrm{~B}_{3}$ & $\mathrm{MDF}^{\mathrm{a}}$ & $\mathrm{L}^{\mathrm{b}}$ & $\mathrm{UF}^{\mathrm{c}}$ & $\mathrm{AS}^{\mathrm{d}}$ & $\mathrm{Wax}$ & $\mathrm{BPH}^{\mathrm{e}}$ & $97 \%$ & $3 \%$ \\
\hline $\mathrm{R}_{94} \mathrm{~B}_{6}$ & $\mathrm{MDF}^{\mathrm{a}}$ & $\mathrm{L}^{\mathrm{b}}$ & $\mathrm{UF}^{\mathrm{c}}$ & $\mathrm{AS}^{\mathrm{d}}$ & $\mathrm{Wax}$ & $\mathrm{BPH}^{\mathrm{e}}$ & $94 \%$ & $6 \%$ \\
\hline $\mathrm{R}_{91} \mathrm{~B}_{9}$ & $\mathrm{MDF}^{\mathrm{a}}$ & $\mathrm{L}^{\mathrm{b}}$ & $\mathrm{UF}^{\mathrm{c}}$ & $\mathrm{AS}^{\mathrm{d}}$ & $\mathrm{Wax}$ & $\mathrm{BPH}^{\mathrm{e}}$ & $91 \%$ & $9 \%$ \\
\hline
\end{tabular}

${ }^{\mathrm{a}}$ Medium density fiberboard. ${ }^{\mathrm{b}}$ Lignocellulosic. ${ }^{\mathrm{c}}$ Urea formaldehyde. ${ }^{\mathrm{d}}$ Ammonium sulfate.

${ }^{\mathrm{e}}$ Borax pentahydrate.

\section{Fiber analysis}

Wood fiber contains $70 \%$ hardwoods and $30 \%$ softwood fibers in this study. These fibers are sieved by means of an Imal Ultrasonic Analysis machine. The fiber analysis diagram is shown in Figure 3. 


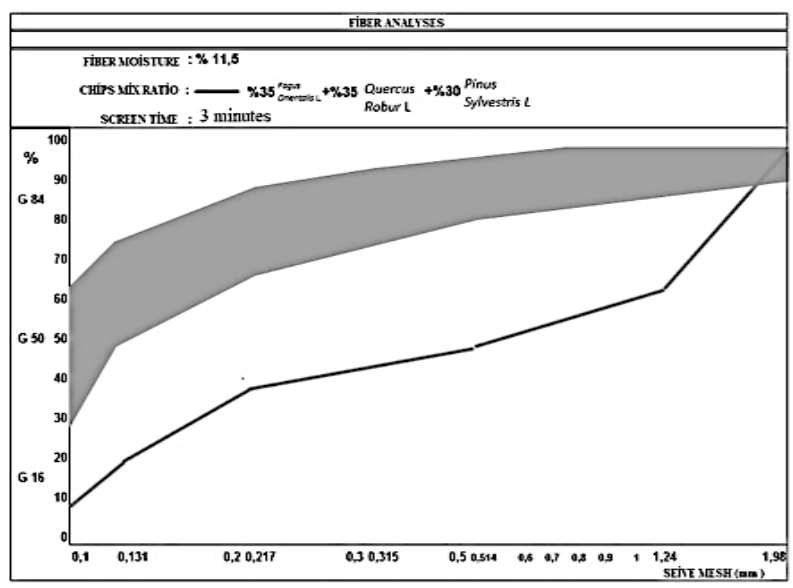

Figure 3: Analysis of the fiber.

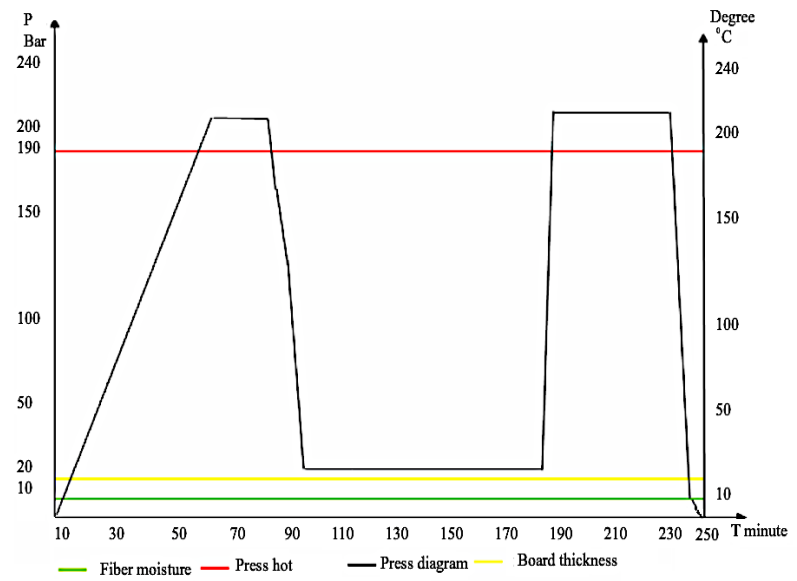

Figure 4: Hot press diagrams.

The hot press diagram in Figure 4 was applied in the production of MDF boards.

\section{Boards manufacturing}

Firstly, the hardwood and softwood species were obtained from the Western Black Sea forests, and then these species were chopped and stored one by one in silos according to the production parameters. Chips used in production were applied to cooking for 4,5 minutes at the vapor pressure of $7,6 \mathrm{~kg} / \mathrm{cm}^{2}$ pressure and $190^{\circ} \mathrm{C}$ temperature in Asplund defibrillator. Chips cooked in Asplund defibrillator were made into fibers in segments. The solid ratio of the urea-formaldehyde was reduced to $50 \%$ solid level in the production process. The color of the ammonium sulfate crystal grains was off white. It was prepared for hardener with the $20 \%$ solution, and then it was injected from a single point to blow line. The color of liquid paraffin was cream and the fat content is up to $2 \%$. The penetration of the liquid paraffin was 32, and then it was stored in the reserve tank as the liquid state. It was mixed the liquid paraffin with a maximum ratio of up to $1,5 \%$ to dry fiber. The mixture having the above-mentioned properties was made of fibers in an Asplund defibrator. The hardener, borax pentahydrate solution and urea-formaldehyde were injected from the blow line to the biomass fiber. These applications (preparation of the resin, inorganic borax pentahydrate solution and other chemicals) were shown in Figure 2.

Fibers included the borax pentahydrate and the chemical was dried at the drier line up to $12 \%$. Dried fibers 
were placed on the mat in the mechanical station. The matformer process were shown in Figure 5. The mat was produced by pressing in the multiday hot press. The pressing parameters were $190{ }^{\circ} \mathrm{C}, 2 \mathrm{~kg} / \mathrm{cm}^{2}$ and 275 seconds. The multiday hot press diagrams application were shown in Figure 4. The dimensions of the panel were $2100 \times 4900 \times 18 \mathrm{~mm}$. After the production of the panels, they were kept in pre-storage for 5 days. The panels were acclimatized in the storage area. These applications were shown in Figure 6 . Then the level of moisture was adjusted to $7,5 \%$. After this process, the top and bottom surfaces of panels were sanded with 40-80-120 degrees sandpaper.

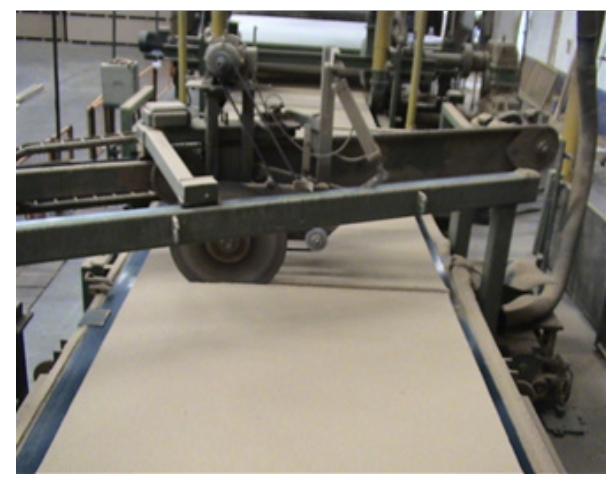

Figure 5: MDF matformer process.

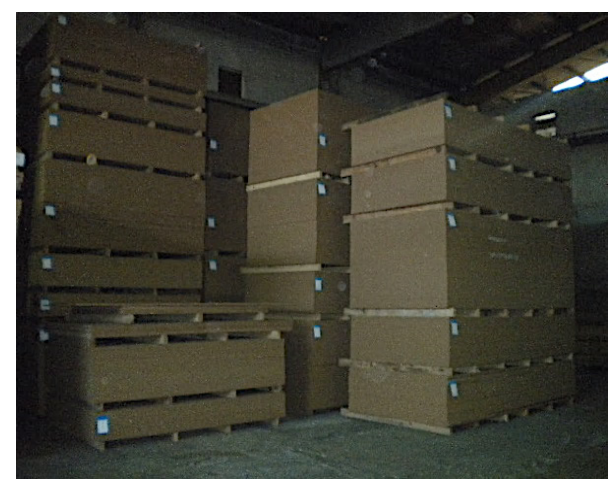

Figure 6: Borax pentahydrate additive MDF products.

\section{Physical test method}

Physical properties were tested according to TS-EN 622-5 (2008) and the density of panels was tested according to TS EN 323 (1999). The water absorption test and the thickness swelling test of the specimens were made according to TS-EN 317 (2008). The sheet surface toluene was made according to the TS EN 382-1 (1999). Sample thickness and length of specimens were measured by using a digital micrometer and compass with $0,01 \mathrm{~mm}$ gradients. The surface color parameter test of the fiberboard was used by elrepho spectrophotometer according to ASTM D 2244-07e1 (2007).

\section{Color properties}

Color measurements were measured by using the tristimulus photoelectric colorimeter Elrepho Spectrophotometer, with a measuring head of $50 \mathrm{~mm}$ in diameter according to ASTM D 2244-07e1 (2007) standards. The Elrepho spectrophotometer was measured the color of any material in a three-dimensional color area (Figure 7). This system which is called CIE L*a*b* operates according to the CIE Standard. The part of the coordinate system interested in this study is the first quadrant which corresponds to positive values of $a^{*}$ and $b^{*}$. The color parameters $\mathrm{L}^{*}, \mathrm{a}^{*}$, and $\mathrm{b}^{*}$ were determined by the CIEL*a*b* method on the surface fiberboards. Their variations concerning the treatment $\left(\Delta \mathrm{L}^{*}, \Delta \mathrm{a}^{*}, \Delta \mathrm{b}^{*}\right)$ was calculated. The color sphere as the 
circle of the cross-section at $\mathrm{L}^{*}=50$ was defined. The color difference, $\Delta \mathrm{E}$ total color difference is the distance between two color points in the color sphere. To the right: Cross section at $\mathrm{L}^{*}=50$ showing the axis from green to red $\left(\mathrm{a}^{*}\right)$ and from blue to yellow $\left(\mathrm{b}^{*}\right)$, the coordinates chroma $\left(\mathrm{C}^{*}\right)$ and hue $\left(\mathrm{h}=\arctan \left(\mathrm{b}^{*} / \mathrm{a}^{*}\right)\right)$ is the hues of color: 0 or 360 is red, 90 is yellow, 180 is green and 270 is blue. $\mathrm{L}^{*}$ is the lightness; $100=$ white and $0=$ black. $\mathrm{C}^{*}$ is the chroma or saturation; 0 represents only greyish colors and 60 . These three measured coordinates represented by $\mathrm{L}^{*}, \mathrm{a}^{*}$ and $\mathrm{b}^{*}$ were transformed to $\mathrm{L}^{*}, \mathrm{C}^{*}$ and $\mathrm{h}$ coordinates and $\Delta \mathrm{E}$ total color difference values were found (Akgul et al. 2013).

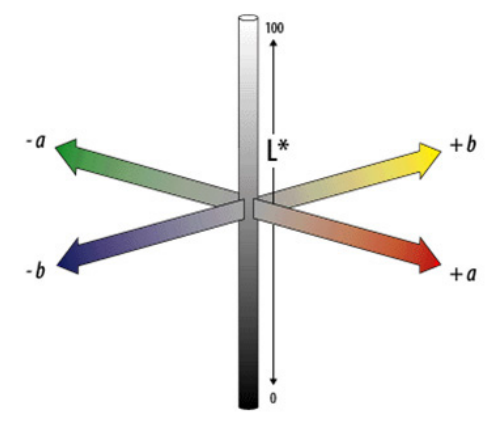

Figure 7: CIELAB the coordinate system shows the color changes in three coordinates which are represented as $\mathrm{L}^{*}, \mathrm{a}^{*}$ and $\mathrm{b}^{*}$ it gives the total color difference equation 1 .

$$
\Delta E=\sqrt{(\Delta L)^{2}+(\Delta a)^{2}+(\Delta b)^{2}}
$$

The average color values, standard deviations, and $5 \%$ significance level based on distribution are calculated by assuming a normal distribution. The lower value of the $\Delta \mathrm{E}$ total color difference shows that the color is not changed or the change of color can be ignored (Akgul et al. 2013).

\section{Mechanical test method}

Cutting and sizing according to TS EN 325 (2008), TS EN 326-1 (1999) standard were performed to specify the properties of MDF plates with inorganic borax pentahydrate. These tests were; bending strength TS EN 310 (2008), modulus of elasticity TS EN 310 (2008), internal bond TS EN 319 (2008). Screw holding ability perpendicular to the plane of panel TS EN 320 (2011), A universal tester (Imal Mobiltemp shc 22, model ib 400) was used to assess mechanical properties. Janka hardness was measured according to ASTM D-1037-78 (1994) standards.

\section{Combustion test method}

We prepared MDF specimens from MDF for the combustion test. The combustion test of borax pentahydrate MDF specimens was determined according to ASTM E 160-50 (1975). These applications are shown in Figure 8. Its conditioned specimens were at $27{ }^{\circ} \mathrm{C} \pm 2{ }^{\circ} \mathrm{C}$ and $30-35 \%$ relative humidity to the targeted equilibrium moisture content of $7 \%$ before the combustion test samples. Twenty-four specimens were stored to make 12 layers forming a square prism (Figure 9). 


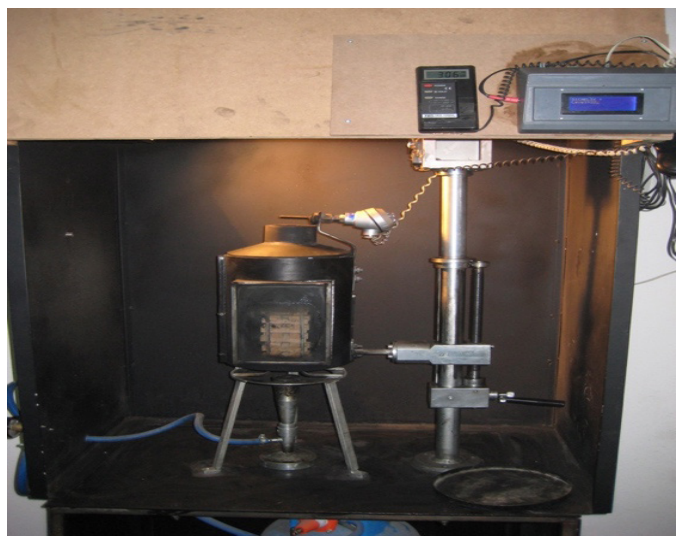

Figure 8: Combustion test apparatus.

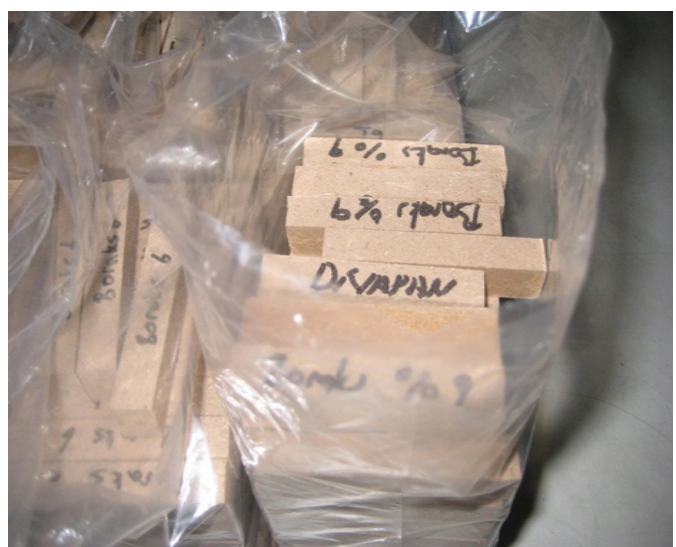

Figure 9: Combustion test samples.

It derived the fire of the heating flame from an LPG tank controlled by a sensitive pascal gauged valve. The flame to the standard height was balanced before the combustion test sample frame. The combustion test method was performed subsequently with the flame stage (FS) and without a flame stage (WFS). The glowing stage (GS) was performed according to ASTM E 160-50 (1975). We recorded temperatures at the combustion column by using thermocouples at 15 and 30-time intervals for combustion with a flame stage and without a flame stage, and a glowing stage, respectively. We calculated the mass loss of the test specimens from the following Equation 2.

$$
\text { mass loss }=\frac{(w b f-w a f}{w b f} \times 100
$$

Where wbf was the weight (g) of a wood specimen before the combustion test, and waf was the weight (g) of a wood specimen after the combustion test. The 936 pieces boards which have additive borax pentahydrate were combusted according to ASTM E 160-50 (1975) standards. The applied tests were FIC (flame-induced combustion), FIC lux (flame-induced combustion lux), SC (self-combustion), SC lux (self-combustion lux), SC time (self-combustion time), ESC (ember situation combustion), ESC lux (ember situation combustion lux), ESC time, mass loss, IST (initial starting temperature), IST time (initial starting temperature-time), IST lux, FC (full Combustion), FC time, (full Combustion time), FC lux (full combustion lux). 


\section{Statistical analysis}

The data concernings physical tests, colour feature tests, mechanical tests and combustion test results were explained \pm standard deviation and were analyzed using an analysis of variance (ANOVA) method for an entirely completely randomized design. Differences were considered statistically substantial at $p<0,05$. As a result of these tests, SPSS 17 (ANOVA) Duncan results are evaluated by statistical programs.

\section{RESULTS AND DISCUSSION}

\section{Physical properties of fiberboard}

The results of ANOVA and Duncan show that the separation test for density, the toluene surface, the thickness swelling (TS, 2-24 hours) and, water absorption (WA, 2-24 hours) percent of the fiberboards made from borax pentahydrate additive fiber and control fiberboards in Table 2. Each test with 20 different samples was measured in this study.

\section{The results of the density test}

Density and mechanical properties of medium fiberboards statistical tests with Duncan's tests are made in the $95 \%$ confidence interval analysis. The results are shown in Table 2. No differences were found between densities for borax pentahydrate added panels $\left(\mathrm{R}_{100} \mathrm{~B}_{0} \mathrm{R}_{97} \mathrm{~B}_{3}, \mathrm{R}_{94} \mathrm{~B}_{6}, \mathrm{R}_{91} \mathrm{~B}_{9}\right)$ according to this statistical analysis. The results of MDF densities were in the range of $650 \mathrm{~kg} / \mathrm{m}^{3}<\mathrm{MDF}<850 \mathrm{~kg} / \mathrm{m}^{3}$ according to TS EN $622-5$ (2008) standards. The density of medium fiberboards affects the used lignocellulosic raw materials, density, moisture content, the width of the heartwood, the width of sapwood, fiber structure and fiber dimensions, the annual ring width, types of cells and, quantity. The mat moisture of the draft of the creation form unit, density, fiber distribution and, press parameters affect the density during production.

Table 2: The results of ANOVA and Duncan mean separation test for density, the toluene surface of the board, the thickness swelling and water absorption percent of the fiberboards are made from borax pentahydrate additive fiberboards and control fiberboard.

\begin{tabular}{|c|c|c|c|c|c|c|c|}
\hline \multirow{2}{*}{\multicolumn{2}{|c|}{$\begin{array}{c}\text { Boards } \\
\text { Borax pentahydrate }\end{array}$}} & \multirow{3}{*}{$\begin{array}{l}\text { Avg.** } \\
715^{\text {a }}\end{array}$} & \multirow{3}{*}{$\begin{array}{c}\text { Std. } \\
\text { Deviation } \\
10\end{array}$} & \multirow{2}{*}{\multicolumn{2}{|c|}{$\begin{array}{c}\text { Board } \\
\text { Borax pentahydrate }\end{array}$}} & \multirow{3}{*}{$\begin{array}{l}\text { Avg.* } \\
41,68^{\mathrm{a}}\end{array}$} & \multirow{3}{*}{$\begin{array}{c}\text { Std. } \\
\text { Deviation } \\
2,87\end{array}$} \\
\hline & & & & & & & \\
\hline \multirow{4}{*}{ 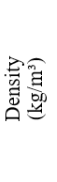 } & $\mathrm{R}_{100} \mathrm{~B}_{0}$ & & & \multirow{4}{*}{ 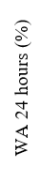 } & $\mathrm{R}_{100} \mathrm{~B}_{0}$ & & \\
\hline & $\mathrm{R}_{97} \mathrm{~B}_{3}$ & $715^{a}$ & 10 & & $\mathrm{R}_{97} \mathrm{~B}_{3}$ & $41,904^{\mathrm{a}}$ & 4,82 \\
\hline & $\mathrm{R}_{94} \mathrm{~B}_{6}$ & $714^{\mathrm{a}}$ & 10 & & $\mathrm{R}_{94} \mathrm{~B}_{6}$ & $52,832^{\mathrm{b}}$ & 4,25 \\
\hline & $\mathrm{R}_{91} \mathrm{~B}_{9}$ & $712^{\mathrm{a}}$ & 10 & & $\mathrm{R}_{91} \mathrm{~B}_{9}$ & $78,400^{c}$ & 11,17 \\
\hline \multirow{4}{*}{$\begin{array}{l}\text { व्ध } \\
\text { 点 } \\
\text { की }\end{array}$} & $\mathrm{R}_{100} \mathrm{~B}_{0}$ & $34,350^{2}$ & 1,09 & \multirow{4}{*}{ 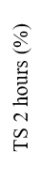 } & $\mathrm{R}_{100} \mathrm{~B}_{0}$ & $3,817^{a}$ & 0,40 \\
\hline & $\mathrm{R}_{97} \mathrm{~B}_{3}$ & $30,300^{b}$ & 1,59 & & $\mathrm{R}_{97} \mathrm{~B}_{3}$ & $6,029^{b}$ & 0,41 \\
\hline & $\mathrm{R}_{94} \mathrm{~B}_{6}$ & $34,100^{\mathrm{a}}$ & 1,41 & & $\mathrm{R}_{94} \mathrm{~B}_{6}$ & $7,023^{c}$ & 0,63 \\
\hline & $\mathrm{R}_{91} \mathrm{~B}_{9}$ & $33,00^{c}$ & 1,97 & & $\mathrm{R}_{91} \mathrm{~B}_{9}$ & $8,480^{d}$ & 1,16 \\
\hline \multirow{4}{*}{ 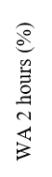 } & $\mathrm{R}_{100} \mathrm{~B}_{0}$ & $21,297^{\mathrm{a}}$ & 2,01 & \multirow{4}{*}{ 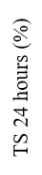 } & $\mathrm{R}_{100} \mathrm{~B}_{0}$ & $10,556^{\mathrm{a}}$ & 0,29 \\
\hline & $\mathrm{R}_{97} \mathrm{~B}_{3}$ & $24,868^{\mathrm{b}}$ & 3,44 & & $\mathrm{R}_{97} \mathrm{~B}_{3}$ & $12,375^{b}$ & 0,75 \\
\hline & $\mathrm{R}_{94} \mathrm{~B}_{6}$ & $35,757^{c}$ & 3,53 & & $\mathrm{R}_{94} \mathrm{~B}_{6}$ & $14,141^{\mathrm{c}}$ & 0,49 \\
\hline & $\mathrm{R}_{91} \mathrm{~B}_{9}$ & $36,836^{\circ}$ & 5,21 & & $\mathrm{R}_{91} \mathrm{~B}_{9}$ & $17,332^{\mathrm{d}}$ & 1,38 \\
\hline
\end{tabular}

"The average value of the samples; Std. (standard deviation)

TS (Thickness swell); WA (Water absorption), BTS (board surface toluene)

$95 \%(\mathrm{p}<0,05)$ the confidence interval for the average ANOVA. a, b, c, d values with the same letter are not different (Duncan's test).

The ratio between the densities for the lowest fiberboard with the average fiberboard is always expected to be between $850 \mathrm{~kg} / \mathrm{m}^{3}$ to $950 \mathrm{~kg} / \mathrm{m}^{3}$. The efficiency of process parameters and the applied hot press diagram in MDF production affect the optimum homogenous density of the fiberboard. If the ratio between the densities for the lowest fiberboard with the average fiberboard near to one number, then this ratio represents 
that the density of the fiberboard is at the optimum homogeneity. Physical and surface properties of fiberboards statistical tests (ANOVA) with Duncan's test are made in the $95 \%$ confidence interval analysis. The results were shown in Table 2. No differences were found between densities for borax pentahydrate added panels $\left(\mathrm{R}_{100} \mathrm{~B}_{0} \mathrm{R}_{97} \mathrm{~B}_{3}, \mathrm{R}_{94} \mathrm{~B}_{6}, \mathrm{R}_{91} \mathrm{~B}_{9}\right)$ according to this statistical analysis result. TS EN 323 (2008) standards are applied in this test. The results of MDF densities were in the range of $650 \mathrm{~kg} / \mathrm{m}^{3}<\mathrm{MDF}<850 \mathrm{~kg} / \mathrm{m}^{3}$ according to TS EN 622-5 (2008) standards. The density of fiberboards affects the used lignocellulosic raw materials, density, moisture content, the width of the heartwood, the width of sapwood, fiber structure and fiber dimensions, the annual ring width, types of cells and quantity. The mat moisture of the draft of the creation form unit, density, fiber distribution and press parameters have affected the density during production. The ratio between the densities for the lowest fiberboard with the average fiberboard was always desired between 850 to $950 \mathrm{~kg} / \mathrm{m}^{3}$. The efficiency of process parameters and the applied hot press diagram in MDF production was affected the optimum homogenous density of the fiberboard.

\section{The result of the swell in water for 2 hours test}

There was a significant difference between $\left(\mathrm{R}_{100} \mathrm{~B}_{0}\right)\left(\mathrm{R}_{97} \mathrm{~B}_{3}\right),\left(\mathrm{R}_{94} \mathrm{~B}_{6}\right)$ and $\left(\mathrm{R}_{91} \mathrm{~B}_{9}\right)$ according to the percentage of TS-2 hours. The brief results were presented in Table 2 . The ratio for this test was $58,26 \%$ for $R_{97} B_{3}$ according to $R_{100} B_{0}$. Therefore, the percentage of TS-2 hours were increased for $R_{97} B_{3}$. Similarly, the ratio was $84,25 \%$ for $R_{94} B_{6}$ according to $R_{100} B_{0}$. Therefore, the percentage of TS-2 hours were increased for $\mathrm{R}_{94} \mathrm{~B}_{6}$. The ratio was $122,57 \%$ for $\mathrm{R}_{91} \mathrm{~B}_{9}$ according to $\mathrm{R}_{100} \mathrm{~B}_{0}$. Therefore, the percentage of TS-2 hours were increased for $\mathrm{R}_{91} \mathrm{~B}_{9}$. Since there was anisotropic swelling of the secondary wall fibers in the cell wall and these fibers in the board lie in different directions and angels, the swelling of the board was the smallest. Hydrophobic materials and water-resistant resin have increased the resistance of the board against such swelling effect. The percentage of swelling of MDF depends on the density of the board, the chemical structure of inorganic borax pentahydrate, the geometrical shape of the borax pentahydrate and the amount of the borax pentahydrate. The quantity of the surface of the board, the density profile of the board, the adhesion strength between the fibers, the length of fibers, the shortness of the fibers have depended on the type and the amount of the paraffin added to MDF.

\section{The result of the swell in water for 24 hours}

There was a significant difference between $\left.\left(\mathrm{R}_{100} \mathrm{~B}_{0}\right),\left(\mathrm{R}_{97} \mathrm{~B}_{3}\right), \mathrm{R}_{94} \mathrm{~B}_{6}\right)$ and $\left(\mathrm{R}_{91} \mathrm{~B}_{9}\right)$ according to the percentage of TS-24 hours. The brief results were shown in Table 2 . The ratio for this test was $17,23 \%$ for $\mathrm{R}_{97} \mathrm{~B}_{3}$ according to $\mathrm{R}_{100} \mathrm{~B}_{0}$. Therefore, the percentage of TS-24 hours increased for $\mathrm{R}_{97} \mathrm{~B}_{3}$. Similarly, the ratio was $33,90 \%$ for $R_{94} B_{6}$ according to $R_{100} B_{0}$. Therefore, the percentage of TS-24h increased for $R_{94} B_{6}$. The ratio was $64,10 \%$ for $R_{91} B_{9}$ according to $R_{100} B_{0}$. Therefore, the percentage of TS-24h increased for $R_{91} B_{9}$. TS EN 317 (2008) standards were applied in this test. Softwood fibers have longer than hardwood fibers. For softwood fibers, the felting ratio, the elasticity ratio and the F factor have higher than the hardwood fibers. For hardwood fibers, the rigid coefficient, the muhlsteph ratio, the runkel ratio and the bulk density value have higher than that of softwood fibers. As the contact angle increase, the adhesion ability increases for softwood fiber according to hardwood fiber. Thus, the entrance of the water and moisture between fibers was more difficult than that of softwood fiber according to hardwood fiber. As the amount of hydrophobic material in the product increases, the swelling in thickness decreased. However, there was a negative effect on the adhesion of fibers.

\section{The results of the water absorption for the 2 hours}

There was a significant difference between $\left(\mathrm{R}_{100} \mathrm{~B}_{0}\right),\left(\mathrm{R}_{97} \mathrm{~B}_{3}\right),\left(\mathrm{R}_{94} \mathrm{~B}_{6}, \mathrm{R}_{91}, \mathrm{~B}_{9}\right)$ according to the percentage of WA-2h. The results were presented in Table 2. The ratio for this test was $16,81 \%$ for $R_{97} B_{3}$ according to $R_{100} B_{0}$. Therefore, the percentage of WA- $2 h$ increased for $R_{97} B_{3}$. Similarly, the ratio was $67,96 \%$ for $R_{94} B_{6}$ according to $R_{100} B_{0}$. Therefore, the percentage of WA- $2 h$ increased for $R_{94} B_{6}$. The ratio was $73,03 \%$ for $R_{91} B_{9}$ according to $\mathrm{R}_{100} \mathrm{~B}_{0}$. Therefore, the percentage of WA-2h increased for $\mathrm{R}_{91} \mathrm{~B}_{9}$.

\section{The results of the water absorption for 24 hours test}

There was a significant difference between $\left(\mathrm{R}_{100} \mathrm{~B}_{0}, \mathrm{R}_{97} \mathrm{~B}_{3}\right),\left(\mathrm{R}_{94} \mathrm{~B}_{6}\right)$ and $\left(\mathrm{R}_{91} \mathrm{~B}_{9}\right)$ according to the percentage of WA-24h. of the brief results were presented in Table 2 . The ratio for this test was $0,527 \%$ for $R_{97} B_{3}$ according to $\mathrm{R}_{100} \mathrm{~B}_{0}$. Therefore, the percentage of WA-24 hours increased for $\mathrm{R}_{97} \mathrm{~B}_{3}$. Similarly, the ratio was $26,75 \%$ for $R_{94} B_{6}$ according to $R_{100} B_{0}$. Therefore, the percentage of WA-24h increased for $R_{94} B_{6}$ and the ratio was $88,08 \%$ for $\mathrm{R}_{91} \mathrm{~B}_{9}$ according to $\mathrm{R}_{100} \mathrm{~B}_{0}$. TS EN 317 (2008) standards were applied in this test. Therefore, 
the percentage of WA-24h increased for $\mathrm{R}_{91} \mathrm{~B}_{9}$. As the amount of inorganic borax pentahydrate was increased in MDF production, the absorption of the water in fiberboards increases as well.

\section{The results of toluene on the surface of the board}

There was a significant difference between $\left(\mathrm{R}_{100} \mathrm{~B}_{0}, \mathrm{R}_{94} \mathrm{~B}_{6}\right),\left(\mathrm{R}_{97} \mathrm{~B}_{3}\right)$ and $\left(\mathrm{R}_{91} \mathrm{~B}_{9}\right)$ and according to the percentage of toluene on the surface of the board test. The ratio for this test decreased $13,36 \%$ for $R_{07} B_{3}$ according to $\mathrm{R}_{100} \mathrm{~B}_{0}$. Therefore, the percentage of BST decreased for $\mathrm{R}_{97} \mathrm{~B}_{3}$. Similarly, the ratio decreased by $0,73 \%$ for $\mathrm{R}_{94} \mathrm{~B}_{6}$ according to $\mathrm{R}_{100} \mathrm{~B}_{0}$. Therefore, the percentage of $\mathrm{BST}$ decreased for $\mathrm{R}_{94} \mathrm{~B}_{6}$. The ratio was 4,09 $\%$ for $\mathrm{R}_{91} \mathrm{~B}_{9}$ according to $\mathrm{R}_{100} \mathrm{~B}_{0}$. Therefore, the percentage of BST decreased for $\mathrm{R}_{91} \mathrm{~B}_{9}$. TS EN 382-1 (2008) standards were applied in this test. The factors affecting the surface quality of the MDF board have affected such; the amount of the inorganic borax pentahydrate filler, the geometry of the inorganic borax pentahydrate filler, the chemical structure, amount of lignin type of cellulosic raw material, density, fiber structure, fiber dimensions, the ratio of fiber moisture, the amount of the resin, hardener and paraffin.

The factors affecting the surface quality during the production of MDF board have affected such as; mat fiber moisture, pulverized sprayed water amount of the top and bottom of the mat, pre-press pressure, hot-pressing parameters and hot press. The applied temperature press and time diagrams during the hot press of the board have especially important. Sanding of MDF, the sanding paper properties, sanding method and sandpaper have affected the smoothness of the board surface.

\section{Color properties}

ASTM D 2244-07el (2007) standards were applied in this test. The surface color analysis of fiberboards was measured using Equation 1. The results were presented in Table 3. The results of ANOVA and Duncan mean separation test for $\Delta \mathrm{L}$ black-white color change, $\Delta \mathrm{a}$ red-green color change, $\Delta \mathrm{b}$ yellow-blue color change, $\Delta \mathrm{E}$ total color difference percent of the fiberboards made from borax pentahydrate additive fiber and control fiberboards are shown in Table 3. Each test with 20 different samples was measured in this study.

Table 3: The results of ANOVA and Duncan mean separation test for $\Delta \mathrm{L}, \Delta \mathrm{a}, \Delta \mathrm{b}, \Delta \mathrm{E}$ per cent of the fiberboards made from borax pentahydrate additive fiber and control fiberboards.

\begin{tabular}{|c|c|c|c|c|c|c|c|}
\hline \multirow{2}{*}{\multicolumn{2}{|c|}{\begin{tabular}{|c|} 
Board \\
Borax pentahydrate
\end{tabular}}} & \multirow{3}{*}{$\begin{array}{l}\text { Avg.* } \\
60,13^{\mathrm{a}}\end{array}$} & \multirow{3}{*}{$\begin{array}{c}\text { Std. } \\
\text { Deviation } \\
0,91\end{array}$} & \multirow{2}{*}{\multicolumn{2}{|c|}{$\begin{array}{c}\text { Board } \\
\text { Borax pentahydrate }\end{array}$}} & \multirow{3}{*}{$\begin{array}{l}\text { Avg. }{ }^{*} \\
17,46^{a}\end{array}$} & \multirow{3}{*}{$\begin{array}{c}\text { Std. } \\
\text { Deviation } \\
0,56\end{array}$} \\
\hline & & & & & & & \\
\hline \multirow{4}{*}{ Ө } & $\mathrm{R}_{100} \mathrm{~B}_{0}$ & & & \multirow{4}{*}{ ४े } & $\mathrm{R}_{100} \mathrm{~B}_{0}$ & & \\
\hline & $\mathrm{R}_{97} \mathrm{~B}_{3}$ & $58,96^{\mathrm{b}}$ & 0,50 & & $\mathrm{R}_{97} \mathrm{~B}_{3}$ & $16,89^{b}$ & 0,28 \\
\hline & $\mathrm{R}_{94} \mathrm{~B}_{6}$ & $57,84^{c}$ & 0,24 & & $\mathrm{R}_{94} \mathrm{~B}_{6}$ & $16,01^{\mathrm{c}}$ & 0,16 \\
\hline & $\mathrm{R}_{91} \mathrm{~B}_{9}$ & $56,02^{\mathrm{d}}$ & 0,44 & & $\mathrm{R}_{91} \mathrm{~B}_{9}$ & $15,48^{d}$ & 0,32 \\
\hline \multirow{4}{*}{$\stackrel{\pi}{\triangleleft}$} & $\mathrm{R}_{100} \mathrm{~B}_{0}$ & $5,62^{a}$ & 0,06 & \multirow{4}{*}{ 凹 } & $\mathrm{R}_{100} \mathrm{~B}_{0}$ & $62,87^{a}$ & 0,98 \\
\hline & $\mathrm{R}_{97} \mathrm{~B}_{3}$ & $5,51^{b}$ & 0,06 & & $\mathrm{R}_{97} \mathrm{~B}_{3}$ & $61,58^{b}$ & 0,53 \\
\hline & $\mathrm{R}_{94} \mathrm{~B}_{6}$ & $5,42^{\mathrm{c}}$ & 0,06 & & $\mathrm{R}_{94} \mathrm{~B}_{6}$ & $60,26^{c}$ & 0,27 \\
\hline & $\mathrm{R}_{91} \mathrm{~B}_{9}$ & $5,19^{d}$ & 0,06 & & $\mathrm{R}_{91} \mathrm{~B}_{9}$ & $58,35^{d}$ & 0,50 \\
\hline
\end{tabular}

*The average value of the samples; Std. (standard deviation)

$\Delta \mathrm{E}^{\mathrm{x}}$ (total color difference); $\Delta \mathrm{L}^{\mathrm{y}}$ (black-white color change); $\Delta \mathrm{a}^{\mathrm{z}}$ (red-green color change); $\Delta \mathrm{b}^{\mathrm{t}}(\mathrm{yellow}-\mathrm{blue}$ color change). $95 \%(\mathrm{p}<0,05)$ the confidence interval for the average ANOVA. a, b, c, d values with the same letter are not different (Duncan's test).

\section{The variation of $\Delta L$}

There was a significant difference between $\left(\mathrm{R}_{100} \mathrm{~B}_{0}\right),\left(\mathrm{R}_{97} \mathrm{~B}_{3}\right),\left(\mathrm{R}_{94} \mathrm{~B}_{6}\right)$ and $\left(\mathrm{R}_{91} \mathrm{~B}_{9}\right)$ in terms of variation. Brief results of Table 3 were explained. This variation decreased by $1,98 \%$ for $422 R_{97} B_{3}$ according to $R_{100} B_{0}$. Similarly, the variation decreased by $3,95 \%$ for $\mathrm{R}_{94} \mathrm{~B}_{6}$ according to $423 \mathrm{R}_{100} \mathrm{~B}_{0}$. Therefore, the variation decreased for $\mathrm{R}_{94} \mathrm{~B}_{6}$. The variation decreased $7,33 \%$ for $\mathrm{R}_{91} \mathrm{~B}_{9} 424$ according to $\mathrm{R}_{100} \mathrm{~B}_{0}$. Therefore, the variation decreased for $\mathrm{R}_{91} \mathrm{~B}_{9}$. 


\section{The variation of $\Delta a$}

There was a significant difference between $\left(\mathrm{R}_{100} \mathrm{~B}_{0}\right),\left(\mathrm{R}_{97} \mathrm{~B}_{3}\right),\left(\mathrm{R}_{91} \mathrm{~B}_{9}\right),\left(\mathrm{R}_{94} \mathrm{~B}_{6}\right)$ and the variations of them. Brief results of Table 3 were explained. This variation decreased by $1,19 \% 430$ for $R_{97} B_{3}$ according to $R_{100} B_{0}$. Similarly, the variation decreased by $3,69 \%$ for $R_{94} B_{6} 431$ according to $R_{100} B_{0}$. Therefore, the variation decreased for $\mathrm{R}_{94} \mathrm{~B}_{6}$. The variation decreased $4328,28 \%$ for $\mathrm{R}_{91} \mathrm{~B}_{9}$ according to $\mathrm{R}_{100} \mathrm{~B}_{0}$. Therefore, the variation decreased for $\mathrm{R}_{91} \mathrm{~B}_{9}$.

\section{The variation of $\Delta b$}

There was a significant difference between $\left(R_{100} B_{0}\right),\left(R_{97} B_{3}\right)$ and $\left(R_{94} B_{6}\right),\left(R_{91} B_{9}\right)$ in terms of variation. Brief results of Table 3 were explained. This variation increased by $3,37 \%$ for $R_{97} B_{3}$ according to $R_{100} B_{0}$. Similarly, the variation decreased by $9,05 \%$ for $R_{94} B_{6}$ according to $R_{100} B_{0}$. Therefore, the variation decreased for $R_{94} B_{6}$. The variation decreased $12,79 \%$ for $440 R_{91} B_{9}$ according to $R_{100} B_{0}$. Therefore, the variation decreased for $\mathrm{R}_{91} \mathrm{~B}_{9}$.

\section{The variation of $\Delta E$}

There was a significant difference between $\left(\mathrm{R}_{100} \mathrm{~B}_{0}\right),\left(\mathrm{R}_{97} \mathrm{~B}_{3}\right)$ and $\left(\mathrm{R}_{94} \mathrm{~B}_{6}\right),\left(\mathrm{R}_{91} \mathrm{~B}_{9}\right)$ in terms of variation. The results of Table 3 were explained. This variation decreased by $2,09 \%$ for $446 R_{97} B_{3}$ according to $R_{100} B_{0}$. Similarly, the variation decreased by $4,33 \%$ for $\mathrm{R}_{94} \mathrm{~B}_{6}$ according to $447 \mathrm{R}_{100} \mathrm{~B}_{0}$. Therefore, the variation decreased for $R_{94} B_{6}$. The variation decreased 7,74\% for $R_{91} B_{9}$ according to $R_{100} B_{0}$. Therefore, the variation decreased for $\mathrm{R}_{91} \mathrm{~B}_{9}$. As the amount of inorganic borax pentahydrate increase in MDF production, the value decreased.

\section{Mechanical properties}

The results of ANOVA and Duncan displays the separation test for bending strength, modulus of elasticity, internal bond, surface screw holding ability, Janka hardness measure vertically to the plate surface of the fiberboards made from borax pentahydrate additive fiber and control fiberboards and are shown in Table 4.

\section{The results of the bending strength test (MOR)}

There was a significant difference between $\left(\mathrm{R}_{100} \mathrm{~B}_{0}, \mathrm{R}_{97} \mathrm{~B}_{3}\right),\left(\mathrm{R}_{94} \mathrm{~B}_{6}, \mathrm{R}_{91} \mathrm{~B}_{9}\right)$ according to the percentage of the bending strength test. Brief results of Table 4 were explained. The ratio for this test was $0,68 \%$ for $R_{97} B_{3}$ according to $R_{100} B_{0}$. Therefore, the percentage of bending strength decreased for $R_{97} B_{3}$. Similarly, the ratio was $26,81 \%$ for $R_{94} B_{6}$ according to $R_{100} B_{0}$. Therefore, the percentage of bending strength decreased for $R_{94} B_{6}$. The ratio was $32,12 \%$ for $R_{91} B_{9}$ according to $R_{100} B_{0}$. Therefore, the percentage of bending strength decreased for $\mathrm{R}_{91} \mathrm{~B}_{9}$. The mechanical properties of the MDF were significant in terms of bending strength. MDF is required to be resistant to the places of use. It was made the bending strength according to the relevant standard. All measurement results of the test boards were measured according to TS EN 622-5 (2008) standard value. Fiber length was the most important factor affecting bending strength. The fiber length and the fibers contact degree are increased with each other's fibers. Thus, a more effective adhesion area is formed. It is boosted the bending strength of the board. The soft wood fiber length has between 6-7 mm. The hard wood fiber length has between 5 and $2 \mathrm{~mm}$. The hard wood fiber wall thickness has thick and the lumen has narrow. This negatively is affected fiber-to-fiber bonding and compression. The fiber wall of softwood has got thin, lumen wide and ellipse. Therefore, it has affected the fiber-fiber bonding and compression factors positively. The blond ratio of MDF to fiber-fiber has increased the tensile strength.

Factors affecting surface quality and bending strength (MOR) of MDF are affected which are the lignocellulosic raw material, the density of the raw material, fiber structures, fiber sizes, fiber moisture content, type of glue, amount of glue, other chemical material, mat moisture content, refiner fibrillation degree, amount of pulverizing water spray of up and down of mat, prepress pressure, hot press type, hot press factors, hot press specific values, hot press temperature, hot press pressure and hot press time. 
Table 4: The results of ANOVA and Duncan mean separation test for density and mechanical properties of the borax pentahydrate additive fiberboards and control fiberboard.

\begin{tabular}{|c|c|c|c|c|c|c|c|}
\hline \multirow{2}{*}{\multicolumn{2}{|c|}{$\begin{array}{c}\text { Board } \\
\text { Borax pentahydrate }\end{array}$}} & \multirow{3}{*}{$\begin{array}{c}\text { Avg. }{ }^{*} \\
3482,915^{\mathrm{a}}\end{array}$} & \multirow{2}{*}{\begin{tabular}{|c|} 
Std. \\
Deviation
\end{tabular}} & \multirow{2}{*}{\multicolumn{2}{|c|}{$\begin{array}{c}\text { Board } \\
\text { Borax pentahydrate }\end{array}$}} & \multirow{3}{*}{$\begin{array}{l}\text { Avg." } \\
10,073^{a}\end{array}$} & \multirow{3}{*}{$\begin{array}{c}\text { Std. } \\
\text { Deviation } \\
0,30\end{array}$} \\
\hline & & & & & & & \\
\hline \multirow{4}{*}{ 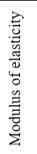 } & $\mathrm{R}_{100} \mathrm{~B}_{0}$ & & 218,22 & \multirow{4}{*}{ 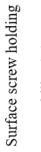 } & $\mathrm{R}_{100 \mathrm{~B}} \mathrm{~B}_{0}$ & & \\
\hline & $\mathrm{R}_{9} \mathrm{~B}_{3}$ & $3447,622^{3}$ & 168,99 & & $\mathrm{R}_{97} \mathrm{~B}_{3}$ & $12,585^{b}$ & 0,42 \\
\hline & $\mathrm{R}_{94} \mathrm{~B}_{6}$ & $2779,268^{b}$ & 164,49 & & $\mathrm{R}_{94} \mathrm{~B}_{6}$ & $9,757^{2}$ & 0,81 \\
\hline & $\mathrm{R}_{91} \mathrm{~B}_{9}$ & $2594,864^{\circ}$ & 127,31 & & $\mathrm{R}_{91} \mathrm{~B}_{9}$ & $7,441^{\circ}$ & 0,67 \\
\hline \multirow{4}{*}{ 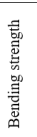 } & $\mathrm{R}_{100} \mathrm{~B}_{0}$ & $36,894^{2}$ & 2,44 & \multirow{4}{*}{ 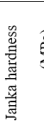 } & $\mathrm{R}_{1000} \mathrm{~B}_{0}$ & $81,05^{2}$ & 1,23 \\
\hline & $\mathrm{R}_{97} \mathrm{~B}_{3}$ & $36,647^{\mathrm{a}}$ & 1,55 & & $\mathrm{R}_{97} \mathrm{~B}_{3}$ & $79,60^{b}$ & 2,23 \\
\hline & $\mathrm{R}_{94} \mathrm{~B}_{6}$ & $29,090^{b}$ & 1,46 & & $\mathrm{R}_{94} \mathrm{~B}_{6}$ & $77,20^{\circ}$ & 1,15 \\
\hline & $\mathrm{R}_{91} \mathrm{~B}_{9}$ & $27,921^{c}$ & 1,58 & & $\mathrm{R}_{91} \mathrm{~B}_{9}$ & $78,50^{\mathrm{d}}$ & 2,04 \\
\hline \multirow{4}{*}{ 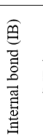 } & $\mathrm{R}_{100 \mathrm{~B}} \mathrm{~B}_{0}$ & $0,586^{\mathrm{a}}$ & 0,03 & & & & \\
\hline & $\mathrm{R}_{97} \mathrm{~B}_{3}$ & $0,579^{2}$ & 0,06 & & & & \\
\hline & $\mathrm{R}_{94} \mathrm{~B}_{6}$ & $0,538^{b}$ & 0,08 & & & & \\
\hline & $\mathrm{R}_{91} \mathrm{~B}_{9}$ & $0,246^{\circ}$ & 0,05 & & & & \\
\hline
\end{tabular}

*The average value of the samples; Std. (standard deviation) $95 \%$ confidence interval for the average ANOVA. a, b, c, d values with the same letter are not different (Duncan's test).

During hot pressing, draft (mat) moisture has an important factor. Mat humidity has included $12 \%$. At this humidity value, the top and bottom surfaces of the boards have plasticized during the hot press. Was transferred the pressing heat to the center of the board. The resin cured and the sheet has become stable. The most important factor in wood has the cellulose chain.

\section{The results of the internal bond test (IB)}

There was a significant difference between $\left(\mathrm{R}_{100} \mathrm{~B}_{0}, \mathrm{R}_{97} \mathrm{~B}_{3}\right),\left(\mathrm{R}_{94} \mathrm{~B}_{6}\right)$ and $\left(\mathrm{R}_{91} \mathrm{~B}_{9}\right)$ according to the percentage of internal bond (IB) test. The results of Table 4 were explained. The ratio for this test was $1,03 \%$ for $R_{97} B_{3}$ according to $\mathrm{R}_{100} \mathrm{~B}_{0}$. Therefore, the percentage of the internal bond decreased for $\mathrm{R}_{97} \mathrm{~B}_{3}$. Similarly, the ratio was $8,92 \%$ for $R_{94} B_{6}$ according to $R_{100} B_{0}$. Therefore, the percentage of the internal bond decreased for $R_{94} B_{6}$. The ratio was $138,20 \%$ for $\mathrm{R}_{91} \mathrm{~B}_{9}$ according to $\mathrm{R}_{100} \mathrm{~B}_{0}$. Therefore, the percentage of the internal bond decreased for $\mathrm{R}_{91} \mathrm{~B}_{9}$. The IB strength of the board decreased as the amount of inorganic minerals increases. The mechanical properties for the $9 \%$ inorganic mineral added to the board were the lowest because borax pentahydrate inorganic filler minerals reduced fibers between contact and adhesion strength. The increase in the density of MDF positively affected the internal bond of the board. It was achieved optimum efficiency in the press diagram. MDF production was applied to the press diagram in Figure 4. During pressing; temperature, pressure and time diagrams were applied.

\section{The results of the modulus of elasticity test (MOE)}

There was a significant difference between $\left(\mathrm{R}_{100} \mathrm{~B}_{0}, \mathrm{R}_{97} \mathrm{~B}_{3}\right),\left(\mathrm{R}_{94} \mathrm{~B}_{6}\right),\left(\mathrm{R}_{91} \mathrm{~B}_{9}\right)$ according to the percentage of the modulus of elasticity test. The brief results of Table 4 were explained. The ratio for this test was $1,02 \%$ for $R_{97} B_{3}$ according to $R_{100} B_{0}$. Therefore, the percentage of modulus of elasticity decreased for $R_{97} B_{3}$. Similarly, the ratio was $25,32 \%$ for $\mathrm{R}_{94} \mathrm{~B}_{6}$ according to $\mathrm{R}_{100} \mathrm{~B}_{0}$. Therefore, the percentage of modulus of elasticity decreased for $\mathrm{R}_{94} \mathrm{~B}_{6}$. The ratio was $34,22 \%$ for $\mathrm{R}_{91} \mathrm{~B}_{9}$ according to $\mathrm{R}_{100} \mathrm{~B}_{0}$. Therefore, the percentage of modulus of elasticity decreased for $\mathrm{R}_{91} \mathrm{~B}_{9}$. In MDF production, the fiber length increased the modulus of elasticity of the board. The important factors affecting the modulus of elasticity were the chemical, anatomical structure of wood, density, amount of extractive substance, extractive content, $\mathrm{pH}$, the humidity of the mat fiber, press temperature, press pressure and timing diagram, respectively. The more contact and sticking surface between the fibers, the greater the elasticity modulus occurred. As the contact surface between the fibers and the area of adhesion decreases, the elastic modulus of the board decreased. Akgul et al. (2013) have measured the elasticity modulus of the board produced burned pine woods between 2567-2733 (MPa).

\section{The results of the surface screw holding ability test $(\mathbf{N})$}

There was a significant difference between $\left(\mathrm{R}_{100} \mathrm{~B}_{0}, \mathrm{R}_{97} \mathrm{~B}_{3}\right),\left(\mathrm{R}_{94} \mathrm{~B}_{6}\right)$ and $\left(\mathrm{R}_{91} \mathrm{~B}_{9}\right)$ according to the percentage of the surface screw holding ability test. The results were explained in Table 4 . The ratio for this test was $25,02 \%$ for $\mathrm{R}_{97} \mathrm{~B}_{3}$ according to $\mathrm{R}_{100} \mathrm{~B}_{0}$. Therefore, the percentage of the surface screw holding ability decreased for $\mathrm{R}_{97} \mathrm{~B}_{3}$. Similarly, the ratio was $3,23 \%$ for $\mathrm{R}_{94} \mathrm{~B}_{6}$ according to $\mathrm{R}_{100} \mathrm{~B}_{0}$. Therefore, the 
percentage of the surface screw holding ability decreased for $R_{94} B_{6}$. The ratio was $37,37 \%$ for $R_{91} B_{9}$ according to $R_{100} B_{0}$. Therefore, the percentage of the surface screw holding ability decreased for $R_{91} B_{9}$. The screw holding resistance was the most important for mechanical properties. It is related to the surface screw holding strength of the board to the strength of the fiber adhesive. The screw holding test results are standardized in TS EN 622-5 (2008). As the amount of inorganic borax pentahydrate increases in MDF, the surface screw holding ability decreased. Akgul and Çamlıbel (2008) have tested the surface screw holding strength of MDF produced from Rhododendron ponticum. Wood fibers between 121,07-125,42 kp. Yorur et al. (2020) have explained that the highest direct screw withdrawal resistance the test blocks with polyurethane and the lowest direct screw withdrawal resistance the test blocks without a pilot hole drilled in both materials. According to the results, medium density fiberboard was best measured direct screw withdrawal resistance than particleboards.

\section{The results of janka hardness test}

There was a significant difference between $\left(\mathrm{R}_{100} \mathrm{~B}_{0}\right),\left(\mathrm{R}_{97} \mathrm{~B}_{3}\right),\left(\mathrm{R}_{94} \mathrm{~B}_{6}\right)$ and $\left(\mathrm{R}_{91} \mathrm{~B}_{9}\right)$ according to the percentage of Jank hardness test. The results were explained in Table 4 . The ratio for this test decreased by $1,82 \%$ for $R_{97} B_{3}$ according to $R_{100} B_{0}$. Therefore, the percentage of Janka hardness decreased for $R_{97} B_{3}$. Similarly, the ratio decreased by $4,99 \%$ for $R_{94} B_{6}$ according to $R_{100} B_{0}$. Therefore, the percentage of Janka hardness decreased for $\mathrm{R}_{94} \mathrm{~B}_{6}$. The ratio was $3,25 \%$ for $\mathrm{R}_{91} \mathrm{~B}_{9}$ according to $\mathrm{R}_{100} \mathrm{~B}_{0}$. Therefore, the percentage of Janka hardness decreased for $\mathrm{R}_{91} \mathrm{~B}_{9}$. The high surface hardness of MDF has affected the Janka strength and resistance properties of the board positively. The surface hardness of the MDF board was the decisive factor for quality control surface Janka strength of MDF board, the density of the board surface and the strength of the between fibers adhesive. Akgul and Çamlibel (2008) have tested the surface Janka strength of MDF board from Rhododendron ponticum. Wood fibers between $73,08-79,83 \mathrm{MPa}$. The increase in the top and bottom density of the MDF board positively affected the surface strength of the board. Akgul et al. (2013) have measured the Janka strength of the board produced burned pine woods between 72,40-77,90 (MPa).

\section{The combustion experiment results of MDF boards}

Table 5 are showed FIC, FIC lux, SC, SC lux, ESC, ESC lux ESC time and mass loss experiments result according to ANOVA Duncan for MDF board which have additive borax pentahydrate. The temperature measured as $\mathrm{R}_{100} \mathrm{~B}_{0}\left(560,21{ }^{\circ} \mathrm{C}\right), \mathrm{R}_{97} \mathrm{~B}_{3}\left(491,91{ }^{\circ} \mathrm{C}\right), \mathrm{R}_{94} \mathrm{~B}_{6}\left(434,04{ }^{\circ} \mathrm{C}\right), \mathrm{R}_{91} \mathrm{~B}_{9}\left(428,91{ }^{\circ} \mathrm{C}\right)$ in the FIC experiment for the produced boards. The results of Table 5 and Table 6 are explained. When the FIC temperature of $560,21^{\circ} \mathrm{C}$ for $\mathrm{R}_{100} \mathrm{~B}_{0}$ boards with the additive inorganic mineral was compared, it was increased the panel resistance $491,91^{\circ} \mathrm{C}$ for $\mathrm{R}_{97} \mathrm{~B}_{3}$ of FIC temperature as the amount of the additive inorganic mineral. It was measured the $434,04{ }^{\circ} \mathrm{C}$ for $\mathrm{R}_{94} \mathrm{~B}_{6}$ highest FIC temperature in the control board as $560,21^{\circ} \mathrm{C}$ in the control board. The FIC temperature $428,91{ }^{\circ} \mathrm{C}$ for $\mathrm{R}_{91} \mathrm{~B}_{9}$ board, decreased as the amount of the additive inorganic mineral in MDF increases. Therefore, the $428,91{ }^{\circ} \mathrm{C}$ heat is absorbed in MDF, which is produced with borax pentahydrate mineral, and $\mathrm{R}_{91} \mathrm{~B}_{9} \mathrm{MDF}$ board $428,91{ }^{\circ} \mathrm{C}$ has resistive properties against combustion.

Table 5: The statistical results for FIC, FIC lux, SC, SC lux, ESC, ESC lux ESC time and mass loss experiments of MDF board which have additive borax pentahydrate according to ANOVA Duncan.

\begin{tabular}{|c|c|c|c|c|c|c|c|}
\hline \multicolumn{2}{|c|}{ Board } & \multirow{2}{*}{ Avg. ${ }^{*}$} & Std. & & ioard & \multirow{2}{*}{ Avg. ${ }^{*}$} & Std. \\
\hline \multicolumn{2}{|c|}{ Borax pentahydrate } & & Deviation & \multicolumn{2}{|c|}{\begin{tabular}{|l|} 
Borax pentahydrate \\
\end{tabular}} & & Deviation \\
\hline \multirow[b]{2}{*}{ 崫 } & $\mathrm{R}_{100 \mathrm{~B}_{0}}$ & $560,21^{2}$ & 17,98 & \multirow{4}{*}{ 鄫 } & $\mathrm{R}_{100 \mathrm{~B}}$ & $309,00^{2}$ & 2,83 \\
\hline \multirow{2}{*}{ 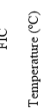 } & $\mathrm{R}_{9} \mathrm{~B}_{3}$ & $491,91^{b}$ & 5,07 & & $\mathrm{R}_{9} \mathrm{~B}_{3}$ & $251,04^{\mathrm{b}}$ & 9,72 \\
\hline & $R_{9} B_{6}$ & $434,04^{c}$ & 289 & & $\mathrm{R}_{94 \mathrm{~B}_{6}}$ & $241,62^{b}$ & 7,36 \\
\hline & $\mathrm{R}_{9 \mathrm{~B}} \mathrm{~B}_{9}$ & $428,91^{\circ}$ & 18,15 & & $\mathrm{R}_{91} \mathrm{~B}_{9}$ & $239,04^{\mathrm{b}}$ & 2,53 \\
\hline \multirow{4}{*}{ 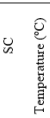 } & $\mathrm{R}_{100 \mathrm{~B}}$ & $662,57^{\mathrm{a}}$ & 6,64 & \multirow{4}{*}{ 曾 } & $\mathrm{R}_{100 \mathrm{~B}} \mathrm{~B}_{0}$ & $302,42^{\mathrm{a}}$ & 24,86 \\
\hline & $\mathrm{R}_{9} \mathrm{~B}_{3}$ & $634,89=\mathrm{ab}$ & 8,50 & & $\mathrm{R}_{9} \mathrm{~B}_{3}$ & $281,75^{\mathrm{a}}$ & 3,89 \\
\hline & $\mathrm{R}_{94} \mathrm{~B}_{6}$ & $559,93^{\mathrm{b}}$ & 42,61 & & $R_{44 B_{6}}$ & $285,68^{\mathrm{a}}$ & 0,88 \\
\hline & $\mathrm{R}_{9 \mathrm{~B} 9}$ & $450.47^{\circ}$ & 37.96 & & $R_{91 B 9}$ & $271.04^{2}$ & 20.39 \\
\hline \multirow{4}{*}{ 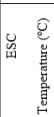 } & RiooBo & $652.57^{2}$ & 18.99 & \multirow{4}{*}{$\begin{array}{l}\text { 鄫 } \\
\text { 幽 } \\
\text { 出 }\end{array}$} & RlocBo & $302.57^{2}$ & 19.19 \\
\hline & $\mathrm{R}_{9} \mathrm{~B}_{3}$ & $400,58^{b}$ & 1,29 & & R9:B3 & $281,16^{x}$ & 8.25 \\
\hline & $\mathrm{R}_{91} \mathrm{~B}_{6}$ & $353,75^{b}$ & 33,59 & & $R_{99 B 6}$ & $226,12^{b}$ & 23,16 \\
\hline & $\mathrm{R}_{91} \mathrm{~B}_{9}$ & $237,50^{\mathrm{c}}$ & 24,75 & & R91B9 & $250,00^{26}$ & 21,21 \\
\hline \multirow{4}{*}{ 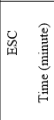 } & $\mathrm{R}_{100 \mathrm{~B}}$ & $64,33^{\mathrm{a}}$ & 0,95 & \multirow{4}{*}{ 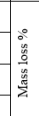 } & $\mathrm{R}_{100 \mathrm{~B}_{0}}$ & $96,35^{2}$ & 0,07 \\
\hline & $\mathrm{R}_{9} \mathrm{~B}_{3}$ & $68,25^{b}$ & 1,06 & & $\mathrm{R}_{9} \mathrm{~B}_{3}$ & $95,75^{2}$ & 0,21 \\
\hline & $R_{9}+B_{6}$ & $71,50^{\mathrm{c}}$ & 0,00 & & $\mathrm{R}_{4} \mathrm{~B}_{6}$ & $94,45^{\mathrm{b}}$ & 0,64 \\
\hline & $\mathrm{R}_{9} \mathrm{~B}_{9}$ & $58,50^{d}$ & 0,71 & & $\mathrm{R}_{91} B_{9}$ & $91,15^{\mathrm{c}}$ & 0,21 \\
\hline
\end{tabular}

*The average value of the samples; Std. (standard deviation) $95 \%$ confidence interval for the average ANOVA.

a, b, c, d values with the same letter are not different (Duncan's test). 
Table 6 are showed FIC temperature, FIC lux, SC temperature, SC lux, IST temperature, IST time, IST lux, FC temperature, FC time, FC lux, IST time and mass loss experiments result according to ANOVA Duncan for MDF board having additive borax pentahydrate. $\mathrm{SC}$ temperatures were measured as $662,57{ }^{\circ} \mathrm{C}$ for $\mathrm{R}_{100} \mathrm{~B}_{0}$, $634,89{ }^{\circ} \mathrm{C}$ for $\mathrm{R}_{97} \mathrm{~B}_{3}, 559,93{ }^{\circ} \mathrm{C}$ for $\mathrm{R}_{94} \mathrm{~B}_{6}, 450,47^{\circ} \mathrm{C}$ for $\mathrm{R}_{91} \mathrm{~B}_{9}$ in the $\mathrm{SC}$ temperature experiment. The value of temperature $450,47^{\circ} \mathrm{C}$ decreased and this reduction was responsible for the chemical properties of the borax pentahydrate mineral. ESC temperatures were measured as $65,57^{\circ} \mathrm{C}$ for $\mathrm{R}_{100} \mathrm{~B}_{0}, 400,58^{\circ} \mathrm{C}$ for $\mathrm{R}_{97} \mathrm{~B}_{3}, 353,75^{\circ} \mathrm{C}$ for $\mathrm{R}_{94} \mathrm{~B}_{6}$, and $237,50^{\circ} \mathrm{C}$ for $\mathrm{R}_{91} \mathrm{~B}_{9}$ in the ESC temperature experiment. ESC temperature decreased as the ratio of inorganic mineral usage increases. ESC Time results were 64,33 minute for $\mathrm{R}_{100} \mathrm{~B}_{0}, 68,25$ minute for $\mathrm{R}_{97} \mathrm{~B}_{3}$, 71,50 minute for $\mathrm{R}_{94} \mathrm{~B}_{6}, 58,75$ minute for $\mathrm{R}_{91} \mathrm{~B}_{9}$. The $\mathrm{R}_{91} \mathrm{~B}_{9}$ boards have the lowest test results.

Table 6: Combustion experiment of additive borax pentahydrate MDF boards.

\begin{tabular}{|c|c|c|c|c|c|c|c|c|c|c|c|c|c|c|}
\hline \multirow[b]{2}{*}{ Board } & \multicolumn{2}{|c|}{$\begin{array}{c}\text { FIC } \\
\text { Average. }\end{array}$} & \multicolumn{2}{|c|}{$\begin{array}{c}\text { SC } \\
\text { Average. }\end{array}$} & \multicolumn{2}{|c|}{$\begin{array}{c}\text { ESC } \\
\text { Average. }\end{array}$} & \multicolumn{3}{|c|}{$\begin{array}{c}\text { IST } \\
\text { Average }\end{array}$} & \multicolumn{3}{|c|}{$\begin{array}{c}\text { FC } \\
\text { Average }\end{array}$} & \multirow{2}{*}{$\begin{array}{c}\text { IST } \\
\text { Minute }\end{array}$} & \multirow{2}{*}{$\begin{array}{c}\text { Mass } \\
\text { loss } \\
(\%)\end{array}$} \\
\hline & $\begin{array}{c}\text { Temp }^{\star} \\
\left({ }^{\circ} \mathrm{C}\right)\end{array}$ & (Lux) & $\begin{array}{c}\text { Temp }^{\star} \\
\left({ }^{\circ} \mathrm{C}\right)\end{array}$ & (Lux) & $\begin{array}{c}\text { Temp }^{*} \\
\left({ }^{\circ} \mathrm{C}\right)\end{array}$ & (Lux) & $\begin{array}{c}\text { Temp }^{*} \\
\left({ }^{\circ} \mathrm{C}\right)\end{array}$ & $\begin{array}{c}\text { Time } \\
\text { (minute) }\end{array}$ & (Lux) & $\begin{array}{c}\text { Temp }^{*} \\
\left({ }^{\circ} \mathrm{C}\right)\end{array}$ & $\begin{array}{c}\text { Time } \\
\text { (Minute) }\end{array}$ & Lux) & & \\
\hline $\mathrm{R}_{100} \mathrm{~B}_{0}$ & 560,1 & 309 & 662,58 & 302,42 & 652,57 & 302,57 & 654 & 150,0 & 321,0 & 614,0 & 540,0 & 31,0 & 64,3 & 96,40 \\
\hline $\mathrm{R}_{97} \mathrm{~B}_{3}$ & 491,92 & 251,04 & 634,89 & 281,75 & 400,58 & 281,17 & 603,5 & 315,0 & 286,0 & 348,0 & $765,0$. & 281,5 & 71,5 & 95,70 \\
\hline $\mathrm{R}_{94} \mathrm{~B} 6$ & 434,04 & 241,63 & 559,93 & 285,68 & 353,75 & 226,13 & 575,5 & 240,0 & 287,5 & 320,0 & 540,0 & 228,0 & 67,0 & 94,50 \\
\hline $\mathrm{R}_{91} \mathrm{~B}_{9}$ & 428,92 & 239,04 & 450,47 & 271,04 & 237,5 & 250,0 & 365,0 & 260,5 & 260,5 & 237,5 & 465,0 & 250,0 & 58,75 & 91,10 \\
\hline
\end{tabular}

*The average value of the temperature.

FIC lux was measured as 309,00 lux for $\mathrm{R}_{100} \mathrm{~B}_{0}, 25, .04$ lux for $\mathrm{R}_{97} \mathrm{~B}_{3}, 241,62$ lux for $\mathrm{R}_{94} \mathrm{~B}_{6}, 239,04$ lux for $\mathrm{R}_{91} \mathrm{~B}_{9}$ in FIC lux experiment. FIC light density decreased and released dark fog as the amount of inorganic borax pentahydrate materials increases in the additive MDF. SC lux was measured as 302,42 lux for $\mathrm{R}_{100} \mathrm{~B}_{0}$, 281,75 lux for $\mathrm{R}_{97} \mathrm{~B}_{3}, 285,68$ lux for $\mathrm{R}_{94} \mathrm{~B}_{6}, 271,04$ lux for $\mathrm{R}_{91} \mathrm{~B}_{9}$ in $\mathrm{SC}$ lux experiment. ESC lux experiment was tested 302,57 lux for $\mathrm{R}_{100} \mathrm{~B}_{0}, 281,16$ lux $\mathrm{R}_{97} \mathrm{~B}_{3}, 226,12$ lux $\mathrm{R}_{94} \mathrm{~B}_{6}, 250,00$ lux $\mathrm{R}_{91} \mathrm{~B}_{9}$. As the amount of borax pentahydrate minerals increases, the dark fog density of ESC decreased. The mass loss of tests of boards was measured using Equation 2. The mass loss experiment was measured 96,35\% for $\mathrm{R}_{100} \mathrm{~B}_{0}, 95,75 \%$ for $\mathrm{R}_{97} \mathrm{~B}_{3}, 94,45 \%$ for $\mathrm{R}_{94} \mathrm{~B}_{6}, 91,15 \%$ for $\mathrm{R}_{91} \mathrm{~B}_{9}$. As the amount of borax pentahydrate minerals increases in MDF measured resistance to fire increases. According to combustion results, ash amount was more increased.

\section{CONCLUSIONS}

As the amount of inorganic borax pentahydrate increases in MDF production, both the percentage of TS-2h, WA-2h and the percentage of TS-24h, WA-24h increased. board.

The $\mathrm{pH}$ and chemical structure of the borax pentahydrate mineral is suitable for the production of the MDF

As the amount of inorganic borax pentahydrate increases in MDF production physical and mechanical properties decreased. The geometrical structure of borax pentahydrate inorganic filler minerals reduced between fibers contact and adhesion strength.

As the amount of inorganic borax pentahydrate increases in MDF, the surface total color difference of the board acceptable limits decreased in terms of the result of color parameters according to the control board. However, the total color difference and whiteness (black-white color change) over the surface board increased.

The combustion experiments were revealed positive results according to FIC, SC, ESC, FIC lux, SC lux, ESC lux, IST and mass loss. According to test results, the resistance to combustion increased as the amount of the inorganic additive minerals increases.

It is suggested that borax pentahydrate percent $3 \%$ use instead of biomass fiber in MDF production. It is 
suggested that borax pentahydrate percent $9 \%$ use against combustion in MDF manufacture.

\section{ACKNOWLEDGEMENTS}

Republic of Turkey, the Ministry of Science and Industry and Technology and Duzce University supported this study and Divapan Integrated Wood Company as the project of San-Tez 00653. STZ.2010-2.

\section{REFERENCES}

Akgul, M.; Ayrılmış, N.; Camlıbel, O.; Korkut, S. 2013. Potential utilization of burned wood in manufacture of medium density fiberboard. $J$ Mater Cycles Waste Manag 15(2): 195-201. https://doi.org/10.1007/s10163-012-0108-3

Akgul, M.; Çamlıbel, O. 2008. The Manufacture of medium density fiberboards using Rhododendron ponticum L. biomass. Build Environ 43:438-443. https://doi.org/10.1016/j.buildenv.2007.01.003

ASTM. 1994. Standard methods of evaluating the properties of wood-base fiber and particle panel materials. ASTM D-1037-78.1994. ASTM: West Conshohocken, PA, USA.

ASTM. 2007. Standard practice for calculation of color tolerances and color differences from instrumentally measured color coordinates. ASTM. D2244-07e1. 2007. ASTM: West Conshohocken, PA, USA.

ASTM. 1975. Standart test method for combustible properties of terated wood by the crib test. ASTM E 160-50.1975. ASTM: West Conshohocken, PA, USA.

Baysal, E.; Yalinkilic M, K. 2005. A comparative study on stability and decay resistance of some environmentally friendly fire retardant baron compounds. Wood Sci Technol 39(3): 187-198. https://doi.org/10.1007/s00226-005-0289-1

Hafizoglu, H.; Yalinkilic, M.K.; Yildiz, U.C.; Baysal, E.; Peker. H.; Demirci, Z. 1994. Utilization of Turkey's Boron Reserves in Wood Preservation Industry. Project of Turkish Science and Tech. Council (TUBITAK), Code: TOAG-875, 377p (in Turkish). http://www.fao.org/faostat/en/\#data/FO

Istek, A.; Aydemir, D.; Eroğlu, H. 2013. Combustion properties of medium-density fiberboards coated by a mixture of calcite and various fire retardants. Turk J Agric For 37: 642-648. https://journals.tubitak.gov. tr/agriculture/abstract.htm?id=14136

Jiang, J.X.; Yang, Y.L.; Li, C.; Li, J.Z. 2011. Effect of three boron flame retardants on thermal curing behavior of urea formaldehyde resin. J Therm Anal Calorim 105(1): 223-228. https://doi.org/10.1007/s10973011-1307-1

Kurt, R.; Mengeloglu, F.; Meric, H. 2012. The effects of boron compounds synergists with ammonium polyphosphate on mechanical properties and burning rates of wood-HDPE polymer composites. Eur J Wood Wood Prod 70: 177-182. https://doi.org/10.1007/s00107-011-0534-2

LeVan S.; Tran, H.C. 1990. The role of boron in flame retardant treatments. In Proceedings of first international conference on wood protection with diffusible preservatives. Nashville, Tennessee, November 28-30, 1990. Forest Products Research Society. p. 39-41.https://www.fpl.fs.fed.us/documnts/pdf1990/levan90a.pdf

Ozcıfcı A.; Toker, H.; Baysal, E. 2007. Fire properties of laminated veneer lumber treated with some fire retardants. Wood Res-Slovakia 52(4): 37-46. http://www.woodresearch.sk/wr/200704/04.pdf

TS. 2008. Wood-based-panels- Determination of modulus of elasticity in bending and of bending strnght. TS. EN 310. 2008. TSE: Ankara. Turkey. 
TS. 2008. This standard specifies a method of determining the swelling in thickness of flat pressed or drum pressed particleboards, fibreboards and cement bonded particleboards. TS. EN 317. 2008. TSE: Ankara. Turkey.

TS. 2008. Particleboards and fibreboards Determination of tensile strength perpendicular to the plane of the board. TS. EN 319. 2008. TSE: Ankara. Turkey.

TS. 2011. Fibreboards, determination of resistance to withdrawal of screws. TS. EN 320. 2011. TSE: Ankara. Turkey.

TS. 2008. Wood based Panels density specifications. TS. EN 323. 2008. TSE: Ankara. Turkey.

TS. 2008. Wood-based Panels the Determination of dimensions of the test pierces. TS. EN 325. 2008. TSE: Ankara. Turkey.

TS. 1999. Wood-Based Panels- Sampling, cutting and inspection- Part 1: Sampling test pieces and expression of test results. TS. EN 326-1. 1999. TSE: Ankara. Turkey.

TS. 2008. Fibreboards- Determination of surface absorption Part 1: Test method for dry process fibreboards (MDF). TS. EN 382-1. 2008. TSE: Ankara. Turkey.

TS. 2008. Fibreboards-specifications-part-5 Requirements for dry process boards (MDF). TS. EN 622-5. 2008. TSE: Ankara. Turkey.

Taghiyari, H.R.; Nouri, P. 2015. Effects of nano-wollastonite on physical and mechanical properties of medium-density fiberboard. Maderas-Cienc Tecnol 17(4): 833-842. https://doi.org/10.4067/ S0718-221X2015005000072

Taghiyari, H.R.; Behrooz, M.P.; Morrell, J.J. 2016. Effects of wollastonite on the properties of medium-density fiberboard (MDF) made from wood fibers and camel-thorn. Maderas-Cienc Tecnol 18(1): 157-166. https://doi.org/10.4067/S0718-221X2016005000016

Tondi, G.; Haurie, L.; Wieland, S. 2014. Comparison of disodium octaborate tetrahydrate-based and tannin-boron-based formulations as fire retardant for wood structures. Fire Mater 38(3): 381-390. https://doi.org/10.1002/fam.2186

Tsunoda, K. 2001. Preservative properties of vapor-boron-treated wood and wood-based composites. $J$ Wood Sci 47: 149-153. https://doi.org/10.1007/BF00780565

Usta, M.; Ustaömer, D. 2012. Boron compounds for MDF. BioResources 7(1): 437-446. https://ojs.cnr. ncsu.edu/index.php/BioRes/article/view/BioRes_07_1_0437_Ustaomer_Usta_Effects_Boron_Melamine_ MDF

Valcheva, L.; Savov, V. 2015. The effect of thickness of medium density fiberboard produced of hardwood tree species on their selected physical and mechanical properties. In Key Engineering Materials. Trans Tech Publications Ltd. 688: 115-121. https://doi.org/10.4028/www.scientific.net/KEM.688.115

Yang, W.; Qing, Y. 2014. Effect of typical boron compounds on the thermal degradation and combustion properties of Phyllostachys pubescen. Engineering Science 16(4): 51-55. http://en.cnki.com.cn/ Article en/CJFDTotal-GCKX201404010.htm

Yorur, H.; Birinci, E.; Gunay, M.N.; Tor, Ö. 2020. Effects of factors on direct screw withdrawal resistance in medium density fiberboard and particleboard. Maderas-Cienc Tecnol 22(3): 375-384. https://doi.org/10.4067/S0718-221X2020005000311

Yu, L.; Cai, J.; Li, H.; Lu, F.; Qin, D.; Fei, B. 2017. Effects of boric acid and/or borax treatments on the fire resistance of bamboo filament. BioResources 12(3): 5296-5307. https://ojs.cnr.ncsu.edu/index.php/ BioRes/article/view/BioRes_12_3_5296_Yu_Boric_Acid_Borax_Treatments 
Zahedsheijani, R.; Gholamiya, H.; Tarmia, A.; Yousefi, H. 2011. Mass transfer in medium density fiberboard (MDF) modified by $\mathrm{Na}^{+}$montmorillonite $\left(\mathrm{Na}^{+} \mathrm{Mmt}\right)$ nanoclay. Maderas-Cienc Tecnol 13(2): $163-$ 172. https://doi.org/10.4067/S0718-221X2011000200004 